\title{
Effect of acepromazine as an adjuvant to ketamine, midazolam and methadone in the
} chemical restraint of cats

Efeitos da acepromazina como adjuvante a cetamina midazolam e metadona, na contenção química de gatas

Efectos de la acepromazina como complemento del midazolam de ketamina y la metadona sobre la contención química de gatos

Received: 06100/2021 | Reviewed: 06/18/2021 | Accept: 06/19/2021 | Published: 06/20/2021

Bárbara Machado Naspolini Macarini ORCID: https://orcid.org/0000-0001-9506-0396 Federal University of Pelotas, Brazil E-mail: barbaranaspolini@gmail.com

Gustavo Antonio Boff

ORCID: https://orcid.org/0000-0002-5837-5302 Federal University of Pelotas, Brazil E-mail: gustavo_boff@hotmail.com

Caroline Jede de Marco

ORCID: https://orcid.org/0000-0003-4999-0810 Federal University of Pelotas, Brazil E-mail: carol-marco@hotmail.com Joseana de Lima Andrades

ORCID: https://orcid.org/0000-0003-3969-7485 Federal University of Pelotas, Brazil E-mail: joseanadelima2@gmail.com

Claudia Beatriz de Mello Mendes

ORCID: https://orcid.org/0000-0003-1653-2573 Federal University of Pelotas, Brazil

E-mail: claudiabeatrizmm@gmail.com

Samantha Alves Azambuja

ORCID: https://orcid.org/0000-0003-4014-7528 Federal University of Pelotas, Brazil E-mail: sasahalves@gmail.com

Bruna Pires

ORCID: https://orcid.org/0000-0002-3755-6243 Federal University of Pelotas, Brazil E-mail: bruspires@gmail.com

Pâmela Caye

ORCID: https://orcid.org/0000-0002-6456-8100 Federal University of Pelotas, Brazil E-mail: pamiscaye@gmail.com

Thomas Normanton Guim

ORCID: https://orcid.org/0000-0001-8278-1397 Federal University of Pelotas, Brazil E-mail: thomasguim@hotmail.com

Martielo Ivan Gehrcke

ORCID: https://orcid.org/0000-0002-5395-8082 Federal University of Pelotas, Brazil E-mail: martielogehrcke@hotmail.com

\begin{abstract}
This study aimed to evaluate the effectiveness of acepromazine as an adjuvant to ketamine, midazolam and methadone in the chemical restraint and anesthesia of cats undergoing ovariohysterectomy. We allocated 14 cats in two groups: group ketamine (GK), premedicated with ketamine $8 \mathrm{mg} / \mathrm{kg}$, midazolam $0.3 \mathrm{mg} / \mathrm{kg}$ and methadone $0.3 \mathrm{mg} / \mathrm{kg}$ and group acepromazine (GAK), premedicated with acepromazine $0.05 \mathrm{mg} / \mathrm{kg}$ in addition to the above-mentioned drugs. At baseline (T0) and every 5 mins up to 20 mins (T5, T10, T15 and T20) after premedication, the sedation score was evaluated at 0 to 24 points. The sedation score was significantly higher at T5, T10, T15 and T20 in both groups. There were no significant differences in extubation times $(3.7 \pm 1.3 \mathrm{mins}$ in GK; $5.2 \pm 2.6 \mathrm{mins}$ in GAK $)$ and the time to reach
\end{abstract}


a score equal to 0 on the sedation scale ( $88 \pm 63.9 \mathrm{mins}$ in GK; $133 \pm 39.7 \mathrm{mins}$ in GAK); however, the time of anesthetic release was significantly higher in the GAK than in GK $(19.7 \pm 6.5$ mins vs $11 \pm 5.9$ mins $)(P=0.023)$. Sedation was adequate in both groups. The results indicated that the administration of acepromazine did not contribute to sedation in the protocol and could delay the anesthetic release.

Keywords: Anesthesia; Sedatives; Preanesthetic Medication; Dissociative Anesthesia.

\section{Resumo}

O objetivo desse estudo foi avaliar o efeito da acepromazina com adjuvante ao protocolo de cetamina, midazolam e metadona na contenção química e anestesia de gatas submetidas a ovariosalpingohisterectomia. Os animais foram divididos em dois grupos: grupo cetamina (GK), premedicados com cetamina $8 \mathrm{mg} / \mathrm{kg}$, midazolam $0,3 \mathrm{mg} / \mathrm{kg}$ e metadona $0,3 \mathrm{mg} / \mathrm{kg}$, e o grupo acepromazina (GAK), premedicados com acepromazina $0,05 \mathrm{mg} / \mathrm{kg}$ associada aos fármacos citados anteriormente. No momento basal (T0) e a cada 5 minutos até 20 minutos (T5, T10, T15 e T20), após a premedicação, um escore de sedação foi avaliado de 0 a 24 pontos. A sedação foi significativamente maior nos T5, T10, T15 e T20 em ambos os grupos. Não teve diferença significativa nos tempos de extubação (3.7 \pm 1.3 minutos no GK; $5.2 \pm 2.6$ minutos no GAK); e no tempo para alcançar escore igual a 0 na escala de sedação (88 \pm 63.9 minutos no GK; $133 \pm 39.7$ minuto no GAK); entretanto, o tempo de alta anestésica foi significativamente maior no GAK do que no GK $(19.7 \pm 6.5$ minutos contra $11 \pm 5.9$ minutos $)(P=0.023)$. A sedação foi adequada em ambos os grupos. A administração de acepromazina não contribuiu para a sedação e aumentou a o tempo de alta anestésica.

Palavras-chave: Anestesia; Sedativos; Medicação Pré-anestésica; Anestesia dissociativa.

\section{Resumen}

El objetivo de este estudio fue evaluar el efecto de la acepromazina con adyuvante al protocolo de ketamina, midazolam y metadona sobre la contención química y la anestesia de gatos sometidos a ovariosalpingohisterectomía. Los animales fueron divididos en dos grupos: grupo ketamina (GK), premedicado con ketamina $8 \mathrm{mg} / \mathrm{kg}$, midazolam 0,3 mg/kg y metadona $0,3 \mathrm{mg} / \mathrm{kg}$, y el grupo acepromazina (GAK), premedicado con acepromazina 0,05 mg/kg asociado a los fármacos mencionados anteriormente. Al inicio (T0) y cada 5 minutos hasta 20 minutos (T5, T10, T15 y T20), después de la premedicación, se evaluó un puntaje de sedación de 0 a 24 puntos. La sedación fue significativamente mayor en T5, T10, T15 y T20 en ambos grupos. No hubo diferencias significativas en los tiempos de extubación (3,7 $\pm 1,3$ minutos en GK; 5,2 \pm 2,6 minutos en GAK); y a tiempo para lograr una puntuación igual a 0 en la escala de sedación (88 \pm 63,9 minutos en GK; $133 \pm 39,7$ minutos en GAK); sin embargo, el tiempo de descarga anestésico era perceptiblemente más largo en GAK que en GK $(19,7 \pm 6,5$ minutos contra $11 \pm 5,9$ minutos $)(P=0,023)$. La sedación fue adecuada en ambos grupos. La administración de acepromazina no contribuyó a la sedación y aumentó el tiempo de anestésico alto.

Palabras clave: Anestesia; Sedantes; Medicación Préanestésica; Anestesia Dissociativa.

\section{Introduction}

When a cat has been administered a preanesthetic medication the aim is to reduce the stress of the cat and facilitate manipulation by the veterinarian, thus promoting chemical restraint (Volpato et al., 2014). The use of drug combinations can improve sedation, with lower doses and fewer side effects (Mocholi, Belda, Bosmans \& Laredo 2016).

In the veterinary anesthetic routine, one of the most commonly used protocols for the sedation of cats when a preanesthetic is used, is the combination of ketamine, midazolam and an opioid. This combination aims to promote dissociative anesthesia, muscle relaxation, transoperative analgesia and postoperative analgesia (Fantoni \& Garofalo, 2012; Moreno, 2012; Rankin, 2015).

Ketamine has a depressing effect on the myocardium and it ends up stimulating the sympathetic nervous system (Ingwersen, Allen, Dyson, Pascoe, O’Grady, 1988). This action increases the heart rate, cardiac output and blood pressure (Pawson \& Forsyth, 2010). These effects can be reduced with the use of an adjuvants drug, like acepromazine, because this drug is a tranquilizer that produces depression in the central nervous system, vasodilatation and antiarrhythmic effects, and these effects have already been found in studies with dogs (Rankin, 2015; Monteiro, Rabello, Rangel, 2019).

We hypothesized that the addition of acepromazine to this protocol may improve the cardiovascular stability, sedation and anesthetic recovery in cats, in addition to producing dissociative anesthesia, muscle relaxation, sedation and analgesia. The 
objective of this study is to evaluate the sedative effect of acepromazine in association with ketamine, midazolam and methadone in cats subjected to elective ovariohysterectomy $(\mathrm{OH})$.

\section{Methodology}

Fourteen healthy cats subjected to elective $\mathrm{OH}$ were admitted to the Veterinary Hospital of the Federal University of Pelotas (HCV-UFPEL), between March and July 2018. The animals were of indefinite breed, ranged from 9 months to 5 years of age and underwent clinical and laboratory examinations before the anesthetic and surgical procedures. For the surgical procedure, the animals fasted for $12 \mathrm{~h}$. The animals went through an acclimation period of at least 24 hours, in light and dark cycles of 12 hours each. On the day of surgery, they underwent a preanesthetic evaluation wherein their heart rate (HR), respiratory rate $(\mathrm{RR})$, capillary filling times, temperature $\left(\mathrm{T}^{\circ} \mathrm{C}\right)$, hydration, mucous color, cardiac and pulmonary auscultation and blood counts were evaluated. The cats were classified according to the classification system of the American Society of Anesthesiologists (ASA), and only those categorized as ASA I, considered healthy animals, were selected for the study (Brodbelt, Flaherty, Pettifer, 2015). The cats were randomly allocated to two different groups $(n=7)$ and the groups received the following preanesthetic medications: GK - ketamine $8 \mathrm{mg} / \mathrm{kg}$ (Dopalen, ketamine, Ceva, Brazil), midazolam $0.3 \mathrm{mg} / \mathrm{kg}$ (Dormire, midazolam, Cristália, Brazil) and methadone $0.3 \mathrm{mg} / \mathrm{kg}$ (Mytedom, metadona, Cristália, Brazil) and GAK (acepromazine $0.05 \mathrm{mg} / \mathrm{kg}$ (Acepran; acepromazina, Vetnil, Brazil), ketamine $8 \mathrm{mg} / \mathrm{kg}$, midazolam $0.3 \mathrm{mg} / \mathrm{kg}$ and methadone $0.3 \mathrm{mg} / \mathrm{kg}$ ). In both groups, the drugs were administered in the same syringe intramuscularly at a time T0. After the administration of preanesthetic, the cats were evaluated at 5, 10,15 and 20 mins using a sedation scale that added the scores of six different independent parameters (Table 1).

Table 1. Modified numerical rating scale (scores from 0 to 4; $0=$ low, $4=$ high) of six independent parameters used to assess sedation and anesthesia. Sedation is considered to be poor (score 0-3), mild (4-6), moderate (7-10) and profound (11-15) based on the scores. If the score is $>15$, allowing intubation of the animal, it will be considered a state of anesthesia

\begin{tabular}{c|c|c}
\hline Parameter & Response & Value \\
\hline Spontaneous position & Able to stand and walk & 0 \\
\hline & Sedated but standing or sitting & 1 \\
\hline & Lying down but able to react quickly or stand up & 2 \\
\hline Resistance to lateral & Lying down but reacting slowly and has difficulty in standing up & 3 \\
recumbency & Strong resistance & 4 \\
\hline & Moderate resistance & 0 \\
\hline & Slight resistance & 1 \\
\hline
\end{tabular}


Research, Society and Development, v. 10, n. 7, e52410717064, 2021

(CC BY 4.0) | ISSN 2525-3409 | DOI: http://dx.doi.org/10.33448/rsd-v10i7.17064

\begin{tabular}{|c|c|c|}
\hline Response to noise & Normal response & 0 \\
\hline & Listens and moves & 1 \\
\hline & Listens and ear moves & 2 \\
\hline & Hardly perceives & 3 \\
\hline & No response & 4 \\
\hline \multirow[t]{3}{*}{ Jaw relaxation } & Normal & 0 \\
\hline & Slightly reduced & 1 \\
\hline & Greatly reduced & 2 \\
\hline \multirow[t]{3}{*}{ Eyelid reflex } & Normal & 0 \\
\hline & Depressed reflex & 1 \\
\hline & No reflex & 2 \\
\hline \multirow[t]{4}{*}{ Response to pain } & Normal (withdrawal of the limb at a minimal clamping pressure) & 0 \\
\hline & Slow response (withdrawal at a higher clamping pressure) & 1 \\
\hline & $\begin{array}{l}\text { Very slow response (withdrawal at a higher clamping pressure maintained for } \\
\qquad 3 \text { to } 5 \mathrm{~s} \text { ) }\end{array}$ & 2 \\
\hline & No response & 3 \\
\hline
\end{tabular}

Source: Mocholi et al. (2016)

After the evaluation, venous catheterization was performed, and the animals were maintained on fluid therapy with lactated Ringer's solution administered at a rate of $5 \mathrm{~mL} / \mathrm{kg} / \mathrm{h}$. As antibiotic prophylaxis, the animals received an intravenous dose of cephalothin (Cefalotina Sódica, cephalothin, Biochimico, Brazil) $25 \mathrm{mg} / \mathrm{kg}$. For anesthetic induction, propofol (Propovan; propofol, Cristália, Brazil) was administered at a rate of $1 \mathrm{mg} / \mathrm{kg} / \mathrm{min}$ until intubation was possible. The animals were then intubated and kept under general inhalation anesthesia with isoflurane (Isoforine; isoflurane, Cristália, Brazil) using calibrated vaporizers. The anesthetic circuit used was baraka. We evaluated the parameters of HR, RR, systolic blood pressure (SBP) by doppler method, $\mathrm{T}^{\circ} \mathrm{C}$ and oxygen saturation at seven moments: presurgical (M1), during skin incision (M2), opening of the abdominal cavity (M3), clamping of the right ovarian plexus (M4), clamping of the left ovarian plexus (M5), suturing of the abdomen (M6) and suturing of skin (M7). The surgical technique used followed the steps: retroumbilical incision of the skin and muscles, about $3 \mathrm{~cm}$; exposure of the uterine horns; a window was made in the mesovary caudal to the ovarian artery and vein, followed by clamping using the three clamp technique (kelly clamp); section between first and second clamp; a circular suture was made with polyglactin 9103.0 thread (Poliglactina 910, glycolid L 90\%- lactide 10\%, Shalom, Brazil) distal to the third clamp; the process was repeated in the other uterine horn; the cervix was located, and using the three clamps technique (kelly calmp), the uterus was removed, and thus a transfixing suture was made around the uterine stump; to suture 
the musculature and subcutaneous tissue, a simple continuous pattern with polyglactin 9103.0 thread (Poliglactina 910, glycolid L 90\%- lactide 10\%, Shalom, Brazil) was used; for suturing the skin, simple isolated stitches were made with nylon 3.0 (Nylon 3.0, black class II monofilament, Shalom, Brazil) thread. In the event of an increase in the parameters by $20 \%$, fentanyl (Fentanest; fentanyl, Cristália, Brazil) $5 \mathrm{mcg} / \mathrm{kg}$ was administered intravenously. In the immediate postsurgical period, the animals received $0.1 \mathrm{mg} / \mathrm{kg}$ of meloxicam (Maxican; meloxicam, Ourofino, Brazil) and $25 \mathrm{mg} / \mathrm{kg}$ of dipyrone (D-500; dipyrone, Zoetis, Brazil), both intravenously. At the end of the surgery, extubation and recovery times were measured. To assess the recovery time, the Aldrete scale modified for anesthetic release score, was used, that is, the time it took the animals to reach a score greater than 8 was measured according to the scale. (Table. 2). We prescribed meloxicam $0.05 \mathrm{mg} / \mathrm{kg}$ every 24 $\mathrm{h}$ for 3 days, tramadol hydrochloride $2 \mathrm{mg} / \mathrm{kg}$ every $8 \mathrm{~h}$ for 5 days and dipyrone $25 \mathrm{mg} / \mathrm{kg}$ every $8 \mathrm{~h}$ for 5 days.

Table 2. Aldrete scale, modified for anesthetic release score, used at the Veterinary Hospital of the Faculty of Veterinary Medicine and Animal Science at the University of São Paulo

\begin{tabular}{|c|c|c|}
\hline Parameter & Response & Value \\
\hline \multirow[t]{3}{*}{ Consciousness } & Alert & 2 \\
\hline & Responsive & 1 \\
\hline & Nonresponsive & 0 \\
\hline \multirow[t]{4}{*}{ Respiratory system } & $\mathrm{RR}>10$ (breaths minutes) & 2 \\
\hline & $\mathrm{RR}<10$ (breaths minutes) & 1 \\
\hline & Dyspnea/tachypnea & \\
\hline & & 0 \\
\hline \multirow[t]{2}{*}{ Airway } & Absence of secretion & 1 \\
\hline & Presence of secretion & 0 \\
\hline \multirow[t]{3}{*}{ Circulatory } & Strong pulse & 2 \\
\hline & Weak pulse & 1 \\
\hline & Filiform pulse & 0 \\
\hline \multirow[t]{3}{*}{ Mucous colors } & Roseas & 2 \\
\hline & Pale & 1 \\
\hline & Cyanotic & 0 \\
\hline
\end{tabular}

Source: Martins \& Fantoni (2010)

All procedures involving the production, maintenance or use of animals for scientific research (or teaching) purposes are in accordance with the provisions of Law No. 11,794 of 8 October 2008, Decree No. 6899 of 15 July 2009 and the rules issued by the National Council for the Control of Animal Experimentation (CONCEA). Our study received a favorable opinion for its execution by the Ethics Committee on Animal Experimentation, registered with number 23110.001080 / $2018-14$. Informed consent was obtained from the respective owners. For statistical evaluation of the degrees of sedation, we used the 
Friedman test followed by Dunn's test between times and Mann-Whitney U test between groups; for other parameters, we performed an ANOVA followed by the Dunnett's test between times and Student's $t$-test between groups $(P \leq 0.05)$.

\section{Results}

There were no observed statistical differences with regard to the values of age, weight and surgical time of the animals studied. The GK had an average age of $12.5 \pm 4.7$ months, whereas the GAK had an average age of $15.8 \pm 9.5$ months. When we assessed the weight data, GK had an average weight of $3.0 \pm 0.5 \mathrm{~kg}$ and GAK, $2.9 \pm 0.5 \mathrm{~kg}$. In the surgical time evaluation, an average of $74.28 \pm 31.94$ mins was obtained in the GK, whereas in the GAK, this average was $70 \pm 15.11$ mins.

Using the sedation scale, statistically significant difference scores were observed at different times, starting from T0, in both groups. There was an increase in the degree of sedation with time, but there was no significant difference in the sedation between the groups (Table. 3).

Table 3. Sedation score values in cats premedicated with ketamine, midazolam and methadone (group ketamine [GK]) or with acepromazine, ketamine, midazolam and methadone (group acepromazine [GAK]), at baseline, T5 (5 min s after preanesthetic), T10 (10 mins after preanesthetic), T15 (15 mins after preanesthetic) and T20 (20 mins after preanesthetic).

\begin{tabular}{c|c|c|c|c|c|c}
\hline \multirow{2}{*}{ Group } & Measure & $\mathrm{T} 0$ & $\mathrm{~T} 5$ & $\mathrm{~T} 10$ & $\mathrm{~T} 15$ & $\mathrm{~T} 20$ \\
\hline \multirow{2}{*}{$\mathrm{GC}$} & Minimum & 0,0 & 1,0 & 8,0 & 8,0 & 6,0 \\
\hline & $25^{\circ}$ quartile & 0,0 & 1,0 & 9,0 & 9,0 & 10,0 \\
\hline & Median & 0,0 & 7,0 & $\mathbf{1 0 , 0} \mathbf{A}$ & $\mathbf{1 1 , 0} \mathbf{A}$ & $\mathbf{1 2 , 0} \mathbf{A}$ \\
\hline & $75^{\circ}$ quartile & 0,0 & 8,0 & 11,0 & 12,0 & 14,0 \\
\hline \multirow{2}{*}{ GAC } & Maximum & 0,0 & 10,0 & 15,0 & 16,0 & 15,0 \\
\hline & Minimum & 0,0 & 3,0 & 3,0 & 8,0 & 8,0 \\
\hline & $25^{\circ}$ quartile & 0,0 & 4,0 & 8,0 & 10,0 & 10,0 \\
\hline & Median & 0,0 & 8,0 & $\mathbf{1 2 , 0} \mathbf{A}$ & $\mathbf{1 3 , 0} \mathbf{A}$ & $\mathbf{1 3 , 0} \mathbf{A}$ \\
\hline
\end{tabular}

$\dagger$ A: different from T0 Mann-Whitney, $\mathrm{P} \leq 0.05$

There was no difference in the consumption of propofol, and the doses of propofol used for anesthetic induction were $4.14 \pm 1.6 \mathrm{mg} / \mathrm{kg}$ in the $\mathrm{GK}$ and $5.4 \pm 2.7 \mathrm{mg} / \mathrm{kg}$ in the GAK.

While evaluating the clinical parameters during the transoperative period for values in the basal measurement, differences were observed at some time points (Table. 4). In the GK, the HR showed a statistical difference at moments M5 $(188 \pm 37 \mathrm{bpm})$ and M1 (140 $\pm 32 \mathrm{bpm})$. In the GAK, the increase in HR was significant at M4, M5 and M6 (184 $\pm 37,189 \pm$ 
35 and $162 \pm 29 \mathrm{bpm}$, respectively) when compared to that at M1 (126 $\pm 19 \mathrm{bpm})$. There were no significant differences in the HR between the groups.

Table 4. Mean values and standard deviations of the clinical parameters of cats premedicated with ketamine, midazolam and methadone (group ketamine [GK]) or with acepromazine, ketamine, midazolam and methadone (group acepromazine [GAK]), assessed through systolic blood pressure (SBP), heart rate (HR), respiratory rate (RR), body temperature $\left(\mathrm{T}^{\circ} \mathrm{C}\right)$ and oxygen saturation $\left(\mathrm{SO}_{2}\right)$ at M1 (after induction), M2 (skin incision), M3 (celiotomy), M4 (right ovarian plexus clamping), M5 (left ovarian plexus clamping), M6 (celiorraphy) and M7 (dermorraphy).

\begin{tabular}{|c|c|c|c|c|c|c|c|c|c|}
\hline Parameter & Group & Measure & M1 & M2 & M3 & M4 & M5 & M6 & M7 \\
\hline \multirow[t]{4}{*}{ HR } & GK & Median & 140 & 134 & 139 & 176 & $188 \mathrm{~A}$ & 173 & 140 \\
\hline & & $\begin{array}{l}\text { Standard } \\
\text { deviation }\end{array}$ & 32 & 34 & 44 & 40 & 37 & 33 & 32 \\
\hline & GAK & Median & 126 & 110 & 137 & $184 \mathrm{~A}$ & $189 \mathrm{~A}$ & $162 \mathrm{~A}$ & 155 \\
\hline & & $\begin{array}{l}\text { Standard } \\
\text { deviation }\end{array}$ & 19 & 13 & 42 & 37 & 35 & 29 & 34 \\
\hline \multirow[t]{4}{*}{ RR } & GK & Median & 14 & 12 & 12 & 16 & 13 & 12 & 14 \\
\hline & & $\begin{array}{l}\text { Standard } \\
\text { deviation }\end{array}$ & 4 & 0 & 3 & 4 & 6 & 4 & 4 \\
\hline & GAK & Median & 15 & 14 & 16 & 17 & 17 & 18 & 19 \\
\hline & & $\begin{array}{l}\text { Standard } \\
\text { deviation }\end{array}$ & 5 & 5 & 6 & 6 & 8 & 9 & 9 \\
\hline \multirow[t]{4}{*}{ SBP } & GK & Median & 69 & 76 & 97 & $159 \mathrm{~A}$ & $156 \mathrm{~A}$ & $109 \mathrm{~A}$ & 102 \\
\hline & & $\begin{array}{l}\text { Standard } \\
\text { deviation }\end{array}$ & 12 & 20 & 35 & 34 & 38 & 33 & 27 \\
\hline & GAK & Median & 81 & 96 & 103 & $160 \mathrm{~A}$ & $154 \mathrm{~A}$ & $117 \mathrm{~A}$ & 107 \\
\hline & & $\begin{array}{l}\text { Standard } \\
\text { deviation }\end{array}$ & 24 & 34 & 38 & 43 & 49 & 53 & 35 \\
\hline \multirow[t]{3}{*}{$\mathrm{T}^{\circ} \mathrm{C}$} & GK & Median & 38,5 & 37,5 & 37,2 & 37,1 & 36,7 & 36,6 & 38,5 \\
\hline & & $\begin{array}{l}\text { Standard } \\
\text { deviation }\end{array}$ & 0,6 & 1,25 & 1,1 & 1,0 & 1,0 & 0,8 & 0,6 \\
\hline & GAK & Median & 37,9 & $37,1 \mathrm{~A}$ & 36,9 A & 36,7 A & $36,5 \mathrm{~A}$ & $36,2 \mathrm{~A}$ & $\begin{array}{c}36,1 \\
\text { A }\end{array}$ \\
\hline
\end{tabular}




\begin{tabular}{c|c|c|c|c|c|c|c|c|c}
\cline { 2 - 10 } & & $\begin{array}{c}\text { Standard } \\
\text { deviation }\end{array}$ & 0,7 & 0,6 & 0,6 & 0,7 & 0,7 & 0,9 & 0,7 \\
\hline $\mathrm{SO}_{2}$ & $\mathrm{GK}$ & Median & 99 & 98 & 98 & 99 & 98 & 98 & 98 \\
\hline & $\begin{array}{c}\text { Standard } \\
\text { deviation }\end{array}$ & 1 & 1 & 1 & 1 & 1 & 1 & 1 \\
\cline { 2 - 10 } & GAK & Median & 99 & 98 & 98 & 98 & 98 & 99 & 99 \\
\cline { 2 - 10 } & & $\begin{array}{c}\text { Standard } \\
\text { deviation }\end{array}$ & 1 & 1 & 1 & 1 & 1 & 1 & 1 \\
\hline
\end{tabular}

*A: different from M1 after Dunnett's test, $P \leq 0.05$

Regarding respiratory rate and oxygen saturation, there were no statistical differences between the moments of each group and between the groups (Table. 4); these parameters remained stable during the surgical procedure. SBP showed a significant increase in both groups, at M4, M5 and M6 (159 \pm 34, $156 \pm 38$ and $109 \pm 33 \mathrm{mmHg}$ in GK; $160 \pm 43,154 \pm 49$ and $117 \pm 53 \mathrm{mmHg}$ in GAK), when compared to that at M1; however, there were no significant differences in SBP between the groups (Table. 4). Regarding analgesic fentanyl rescues, in GK, 6/7 animals received fentanyl, whereas in GAK, all animals received fentanyl. All analgesic rescues were performed at M4 and M5. No significant differences were observed in these values between the groups. The temperature values were significantly lower at all times compared to that at M1 in the $\operatorname{GAK}\left(37.1 \pm 0.6,36.9 \pm 0.6,36.7 \pm 0.7,36.7 \pm 0.7,36.2 \pm 0.9\right.$ and $36.1 \pm 0.7^{\circ} \mathrm{C}$ at $\mathrm{M} 2, \mathrm{M} 3, \mathrm{M} 4, \mathrm{M} 5, \mathrm{M} 6$ and $\mathrm{M} 7$, respectively). There were no significant differences in the temperature values in GK between times as well as the values between groups (Table. 4). The time of extubation after the end of anesthesia was $3.7 \pm 1.3 \mathrm{mins}$ in the GK and $5.2 \pm 2.6 \mathrm{mins}$ in the GAK; the time to reach a score equal to 0 on the sedation scale was $88 \pm 63.9$ mins in the GK and $133 \pm 39.7$ mins in the GAK. There were no significant differences in these values between the groups. However, when analyzing the data on anesthetic release using the Aldrete scale, the GAK showed a longer time compared to the GK $(19.7 \pm 6.5$ mins vs $11 \pm 5.9$ mins; $P=0.023$ ) (Table. 5).

Table 5. Times, in minutes, of extubation, anesthetic release, and sedation score equal to 0 , of cats pre-medicated with ketamine, midazolam, methadone (Group GK) or with acepromazine, ketamine, midazolam, methadone (Group GAK).

\begin{tabular}{c|c|c|c|c}
\hline & & Extubation & Anesthetic release & Sedation score $=0$ \\
\hline GC & Median & 3,7 & $\mathbf{1 1 , 0} \mathbf{A}$ & 88,0 \\
\hline & Standard deviation & 1,3 & 5,9 & 63,9 \\
\hline GAC & Median & 5,3 & $\mathbf{1 9 , 7} \mathbf{A}$ & 133,3 \\
\hline & Standard deviation & 2,6 & 6,5 & 39,7 \\
\hline
\end{tabular}

*A: different bettwen groups after $\mathrm{t}$ student test, $P \leq 0,05$. 


\section{Discussion}

Preanesthetic protocols containing ketamine are used in cats, especially in the restless ones where physical restraint is difficult (Martins \& Fantoni, 2010). Ketamine is a dissociative anesthetic that is usually associated with benzodiazepines or alpha-2 agonists to minimize the animal's stress and its adverse effects (Marjani, Akbarinejad, Bagheri, 2015). Opioids, associated with tranquilizers or sedatives, are also part of these preanesthetic protocols, providing analgesia and adequate sedation for different types of surgeries and veterinary procedures (Killos, Graham, Lee, 2010; Shah, Yates, Hunt, Murrell, 2018; Steagall, Taylor, Brondoni, Luna, Dixon, 2008). In the present study, both protocols produced a suitable level of sedation during the evaluated period, allowing for the patient's smooth manipulation in preparation for $\mathrm{OH}$.

The administration of an opioid with acepromazine, a combination of sedation and analgesia, generally produces a synergistic effect, thereby increasing the intensity of sedation and analgesia of each drug (Hunt, Grint, Taylor, Murrel, 2014; Steagall et al., 2008).

Additionally, the use of this association in preanesthetic would require less consumption of anesthetics during induction and a more peaceful recovery of the patient (Bortolami, Murrell, Slingsby, 2012; Hunt et al., 2014; Pawson \& Forsyth, 2010). In the present study, there was no reduction in the consumption of propofol used in anesthetic induction in the group that received acepromazine or an increase in the degree of sedation, although the discharge form anesthesia, of the animals that received this drug, was later. These results may have been influenced by the latency time of the use of acepromazine applied intramuscularly because the peak effect occurs in 30 mins when applied by this route (Rankin, 2015). Similar results were found in cats premedicated with acepromazine or medetomidine, demonstrating the low sedative effect of acepromazine in this specie (Schwarz et al., 2014).

According to a study carried out in cats subjected to elective $\mathrm{OH}$, the methadone used in preanesthetic promoted analgesia for up to $6.5 \mathrm{~h}$ after its administration (Fantoni and Garofalo, 2012). In the present study, the significant increase in clinical parameters, indicative of pain during the period of anesthesia, can be explained by the low dose of methadone used $(0.3 \mathrm{mg} / \mathrm{kg})$ and the intensity of the pain generated by traction of the ovarian pedicle. Other researchers claim that methadone at a dose of $0.5 \mathrm{mg} / \mathrm{kg}$ is effective for both intraoperative and postoperative analgesia for up to $6 \mathrm{~h}$ after administration (Shah et al., 2018; Slingsby, Bortolami, Murrell, 2018).

The association of acepromazine with opioids in preanesthetic can cause different adverse effects, such as hypothermia. When using these preanesthetic drugs, associated with general anesthetics and ambient temperature factors, peripheral vasodilation and consequent decrease in body temperature are observed (Bitti et al., 2017; Manfrinate et al., 2009). In the present study, there was significant hypothermia at different times, when compared to that at M1, in the group that received acepromazine.

The latency time after acepromazine administration is relatively long and it produces sedation for at least 2 to $3 \mathrm{~h}$ in the most species (Rankin, 2015). A study that associated ketamine with acepromazine found an increase in the duration of action and effects of ketamine (Steagall et al., 2008). In the present study, the GAK had a longer duration of discharge from the anesthetic because the patients recovered later, in the immediate post anesthetic moment.

Rapid anesthetic recovery is directly linked to the drugs implemented in the protocol and a consequent decrease in body temperature (Robertson et al., 2018). Association of acepromazine with different drugs prolongs its effects, contributing to hypothermia, suggesting that this phenomenon may have occurred in the present study, producing a delayed anesthetic release (Rankin, 2015; Steagall et al., 2009). 
It is important to emphasize that this work was carried out in females, so there may be a difference when these protocols are used in males, as the hormonal influence between genders can affect the absorption and metabolism of the drugs used (Hart, Eckstein, 1997).

\section{Conclusion}

The association of acepromazine with ketamine, midazolam and methadone does not increase the sedation scores, but it promotes a decrease in temperature and delays the anesthetic release.

\section{Acknowledgments}

We would like to thank Editage (www.editage.com) for English language editing.

\section{References}

Bitti, F. S., Campagnol, D., Rangel, P. P., Nunes, J. S. Jr., Loureiro, B., Monteiro, E. R. (2017). Effects of three methadone doses combined with acepromazine on sedation and some cardiopulmonary variables in dogs. Veterinary Anaesthesia and Analgesia, 1-9.

Bortolami, E., Murrell, J. C., Slingsby, L. S. (2012). Methadone in combination with acepromazine as premedication prior to neutering in cat. Veterinary Anaesthesia and Analgesia, 181-193.

Brodbelt, D. C., Flaherty, D., Pettifer, G. R (2015). Anesthetic risk and informed consent. In Grimm, K. A., Lamont, L. A., Tranquilli, W. J., Greene, A. S., Robertson, S. A. Veterinary Anesthesia and Analgesia (5th. ed., Cap. 2, pp. 11-22). Iowa, EUA: Wiley Blackwell.

Fantoni, D. T., Garofalo, N. A. Fármacos analgésicos opioids. (2012). In Fantoni, D. Tratamento da dor na clínica de pequenos animais (Cap. 11, pp. 109126). Rio de Janeiro, RJ: Elsevier.

Hart, B. L, Eckstein, R. A. (1997). The role of gonadal hormones in the occurrence of objectionable behaviours in dogs and cats. Applied Animal Behaviour Science, 52, 331-344.

Hunt, J. R., Grint, N. J., Taylor, P. M., Murrel, J. C. (2014). Sedative and analgesic effects of buprenorphine, combined with either acepromazine or dexmedetomidine, for premedication prior to elective surgery in cats and dogs. Veterinary Anaesthesia and Analgesia, 40, $297-307$.

Ingwersen, W., Allen, D. G., Dyson, D. H., Pascoe, P. J., O’Grady, M. R. (1988). Cardiopulmonary effects of a ketamine hydrochloride/acepromazine combination in healthy cats. Canadian Journal Veterinary Research, 52, 1-4.

Killos, M. B., Graham, L. F., Lee, J. (2010). Comparison of two anesthetic protocols for feline blood donation. Veterinary Anaesthesia and Analgesia., 37, 230-239.

Manfrinate, R., Dahroug, M. A. A., Farias, D. C., Vasconcelos, L. P. S., Wayhs, N. N. S., Monzem, S. ... Guimarães, L. D. (2009). Efeitos da morfina e da metadona associadas à acepromazina em gatas anestesiadas com propofol e halotano e submetidas à ovariossalpingohisterectomia. Acta Scientiae Veterinary, $37(4), 245-251$

Marjani, M., Akbarinejad, V., Bagheri, M. (2015). Comparison of intranasal and intramuscular ketamine-midazolam combination in cats. Veterinary Anaesthesia and Analgesia., 42, 178-181.

Martins, J., Fantoni, D. T. (2010). Recuperação pós-anestésica. In Fantoni, D. T. Anestesia de cães e gatos (2nd. ed., Cap. 12, pp. 217-227). São Paulo, SP: Roca.

Mocholi, D. R., Belda, E., Bosmans, T., Laredo, F. G. (2016). Clinical efficacy and cardiorespiratory effects of intramuscular administration of alfaxalone alone or in combination with dexmedetomidine in cats. Veterinary Anaesthesia and Analgesia., 43, $291-300$.

Monteiro, E. R., Rabello, T.A., Rangel, J. P. P. (2019). Effects of 3 morphine doses, in combination with acepromazine, on sedation and some physiological parameters in dogs. The Canadian Journal of Veterinary Research, 83, 235-240.

Moreno, J. C. D. (2012). Antagonistas de receptores N-metil-D-Aspartato (NMDA). In Fantoni D. Tratamento da dor na clínica de pequenos animais (Cap. 16, pp. 171-201). Rio de Janeiro, RJ: Elsevier.

Pawson, P., Forsyth, S. (2010). Agentes anestésicos. In Maddison, J. E., Page, S. W., Church, D. B. Farmacologia clínica de pequenos animais (Cap. 5, pp. 83-112). Rio de Janeiro, RJ: Elsevier.

Rankin, D. C. (2015) Sedatives and tranquilizers. In Grimm, K. A., Lamont, L. A., Tranquilli, W. J. Veterinary Anesthesia and Analgesia (5th. ed., Cap. 10, pp. 196-206). Iowa, EUA: Wiley Blackwell.

Schwarz, A., Kalchofner, K., Palm, J., Picek, S., Hartnack, S., Wolfensberger, R. B. (2014). Minimum infusion rate of alfaxalone for total intravenous anesthesia after sedation with acepromazine or medetomidine in cats undergoing ovariohysterectomy. Veterinary Anaesthesia and Analgesia., 41, 480-490. 
Research, Society and Development, v. 10, n. 7, e52410717064, 2021

(CC BY 4.0) | ISSN 2525-3409 | DOI: http://dx.doi.org/10.33448/rsd-v10i7.17064

Shah, M. A., Yates, D., Hunt J., Murrell, J. (2018). Comparison between methadone and buprenorphine within the QUAD protocol for perioperative analgesia in cats undergoing ovariohysterectomy. Journal Feline Medicine. Surgery, 21(8), 723-731.

Robertson, S. A., Gogoiski, S. M., Pascoe, P., Shafford, H. L., Sager, J., Griffernhargen, G. M. (2018). AAFP feline anesthesia guidelines. Journal Feline Medicine Surgery, 20, 602-634.

Slingsby, L. S., Bortolami, E., Murrell, J. C. (2018). Methadone in combination with medetomidine as premedication prior to ovariohysterectomy and castration in the cat. Journal Feline Medicine. Surgery. 17(10), 864-872.

Steagall, P. V., Taylor, P. M., Rodrigues, L. C. C., Ferreira, T. H., Minto, B. W., Aguiar, A. J. A. (2009). Analgesia for cats after ovariohysterectomy with either buprenorphine or carprofen alone or in combination. Veterinary Record, 164, 359-363.

Steagall, P. V. M., Taylor, P. M., Brondoni, J. T., Luna, S. P. L., Dixon, M. J. (2008). Antinociceptive effects of tramadol and acepromazine in cats. Journal Feline Medicine. Surgery, 10, 24-31.

Volpato, J., Mattoso, C. R. S., Beier, S. L., Coelho, M. M., Tochedo, R., Kirsten, C. E., Yonezawa, L. A., Saito, M. E. (2014). Sedative, hematologic and hemostatic effects of dexmedetomidine-butorphanol alone or in combination with ketamine in cats. Journal Feline Medicine Surgery, 17(6), 500-506. 